\title{
REKONSTRUKSI KONSEP IJBAR
}

\author{
Taufiq Hidayat \\ STAI An-Nawawi Purworejo \\ Telepon: 081555876010 \\ Email:an-nawa@hotmail.com
}

\begin{abstract}
Marriage is one of the pressing issues mentioned in detail in the Quran and hadis. Sources concerning marriage mirror negotiation between patriarchal authority and equality among believers. Universal nature of the Quran is then interpreted and implemented (tafsir watatbiq) to fit the social and cultural makeup of pre-modern Arab peninsula. Hadis concerning forced marriage was put into the mouth of the prophet to justify the patriarchal authority of pre-modern society, which finds its expression in the books of figh. It is a pity that, despite emancipation of women, tradition demeaning to women dies hard. This paper aims to analyze the concept of forced marriage discussed in the books of medieval figh which is considered outdated due to its violation of women's right to choose their spouse.

Perkawinan adalah salah satu isu yang disebutkan secara rinci dalam Qur'an dan hadis. sumber-sumber hukum yang berbicara tentang pernikahan adalah suatu persolan yang menggambarkan negoisasi antara otoritas patriarkhal dan keadilan bagi orang-orang muslim. ajaran universal Qur'an diinterpretasikan dan diimplementasikan sesuai dengan kebutuhan sosial budaya masyarakat Arab pada masa pra-modern.Hadis yang menjelaskan konsep ijbar yang disampaikan oleh Nabi hanya untuk menyesuaikan otoritas patriarchal pada masa pra-modern yang ditemukan pada kitab-kitab figh. Akan sangat disayangkan apabila tradisi tersebut merugikan perempuan. Tulisan ini bertujuan untuk menganalisa konsep ijbar pada pernikahan yang dibahas dalam kitab-kitab figh abad pertengahan yang dianggap ketinggalan jaman karena tidak melihat hak perempuan dalam memilih pasangan.
\end{abstract}

Keywords: Rekonstruksi, ljbar, Wali, Pernikahan

\section{Pendahuluan}

Isu-isu tentang perempuan adalah permasalahan yang selalu mengandung kontroversi, bahkan menurut kalangan modernis diperlukan adanya rekonstruksi pemikiran untuk menjawab persoalan perempuan. ${ }^{1}$ Sejum-

1 Lebih jelas lihat: M. Hajar Dewantoro dan Asnawi (ed.), Rekonstruksi Fiqh Perempuan dalam Peradaban Masyarakat Modern, (Yogyakarta: Ababil, 1996). lihat juga Husein Muhammad, "Kontekstualisasi Kitab Kuning: Tradisi Kajian dan Metode Pengajaran" dalam Pesantren Masa Depan: Wacana Pemberdayaan dan Transformasi Pesantren, Cet.I. (Bandung: Pustaka Hidayah, 1999). lah jawaban yang diberikan selama ini ternyata belum menuntaskan masalah dan dalam banyak kasus justru memicu ketidakpuasan. Dapat dikatakan bahwa isu keperempuanan dalam Islam merupakan masalah yang kompleks, karena ia bukan sekedar persoalan yang hanya bisa didekati dengan pemaparan final dari doktrin-doktrin keagamaan, akan tetapi menjawab persoalan perempuan juga harus memperhatikan aspek sosial budaya, teologi ataupun sensitifitas gender. Pada dasarnya, akar dari semua persoalan itu adalah berasal dari ide tentang emansipasi wanita. 
Salah satu tuntutan emansipasi wanita adalah ide tentang perlindungan hak reproduksi perempuan yang disepakati pada sebuah konferensi dunia tentang kependudukan dan perempuan (ICPD) yang diadakan di Kairo pada 1994, yang menyepakati bahwa perempuan memiliki hak reproduksinya sendiri yang harus dijaga dan dipelihara. Salah satu isi dari tuntutan hak reproduksi tersebut adalah hak perempuan untuk menentukan pasangan hidupnya sendiri. ${ }^{2}$ Dalam pandangan Islam klasik, hal tersebut dibatasi oleh konsep ijbar yang dipahami oleh masyarakat Indonesia sebagai kawin paksa.

Persoalan ijbar menjadi masalah yang sangat pelik karena di satu pihak konsep ini memiliki pijakan hukum dari fiqh dan di lain pihak, selain tidak selaras dengan tuntutan demokratisasi, konsep ijbar bertentangan dengan prinsip kemerdekaan yang sangat ditekankan oleh agama Islam, yaitu kebebasan memilih jodoh. ${ }^{3}$ Implikasi dari konsep tersebut adalah bahwa seorang anak tidak bisa menentukan apa-apa, sehingga seorang gadis yang akan dikawinkan, mungkin tidak mengenal wajah calon suaminya hingga hari pernikahannya. Akan tetapi karena pengaruh modernitas, hak ijbar kini mulai memudar. Hanya masyarakat tertentu saja yang masih memegang teguh dan melaksanakan konsep ijbar dengan bersandar pada dogma-dogma agama. Namun dewasa ini perlu adanya upaya verifikasi terhadap konsep ijbar, karena masih didapati pemahaman yang berbeda di kalangan ulama dalam memahami had is ${ }^{4}$ yang dijadikan argumen konsep ini.

${ }^{2}$ Syafiq Hasyim, Hal-Hal Yang Tak Terpikirkan Tentang Isu-isu Keperempuanan Dalam Islam, (Bandung: 2001), h. 181.

3 Masdar F. Mas'udi, Islam dan Hak-Hak Reproduksi Perempuan; Dialog Fiqh Pemberdayaan, edisi revisi, cet. I, (Bandung: Mizan, 1998), h. 97.

${ }^{4}$ Kajian hadis harap dipahami terhadap sejumlah hadis Nabi secara tekstual ataupun kontektual menurut tuntunan masing-masing. Melalui telaah ma'anil hadis diharapkan muncul bukti-bukti dalam berbagai hadis Nabi, terkandung ajaran Islam yang bersifat Universal, temporal, dan atau lokal. Lihat. Ismail, M. Syuhudi, Hadis Nabi yang Tekstual dan Kontektual telaah Ma'anil Hadis yang Universal, Temporal dan Lokal, (Jakarta: Bulan Bintang, 1994), h. 7.

\section{Ijbar Sebagai Doktrin Agama}

Landasan dari konsep ijbar ditemukan dalam hadis nabi yang termuat dalam berbagai kitab-kitab hadis seperti pada Shahih Bukhari dalam Kitab al-Ikrah, Shahih Muslim dan Sunan al-Tirmidzi. Nomor hadis pada tulisan ini didasarkan pada penomoran dalam Mausu'ah Kutub al-Sittah format disk.

Shahih Bukhari, Kitab al-Ikrah, no. $6433^{5}$

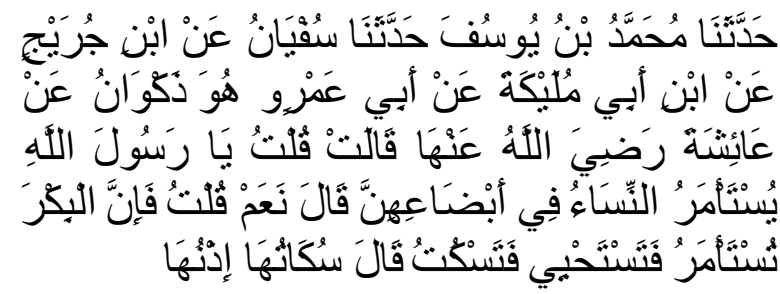

Shahih Muslim, Kitab al-Nikah, no. $2546^{6}$

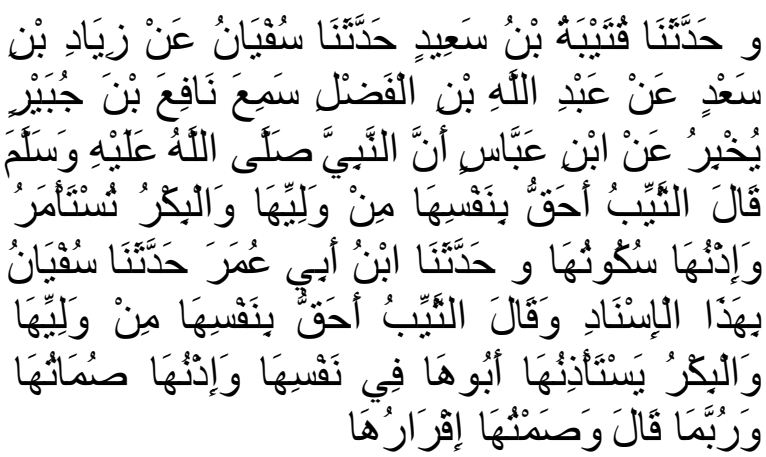

Sunan al-Nasa'i, Kitab al-Nikah, no. 3212

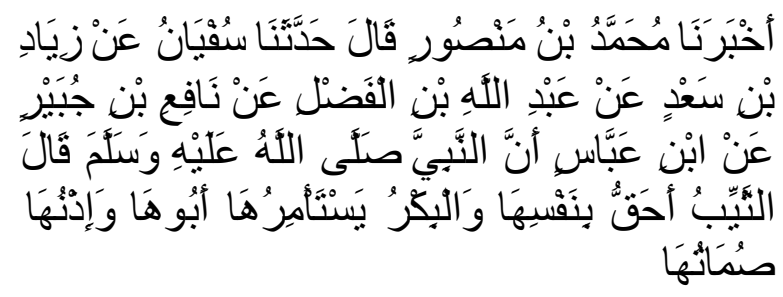

Adapun hadis-hadis yang meminta persetujuan mempelai perempuan ditemukan dalam Shahih Bukhari pada Bab al-Nikah,

5 Syarah dari hadis ini menyebutkan bahwa terdapat peselisihan pendapat dikalangan ulama tentang ijbar tehadap gadis yang sudah dewasa, tetapi terhadap gais kecil dibolehkan. Lihat Kitab Fatkhul Bari

6 Abu Husein Muslim, Sahih Muslim, (Beirut:Daral-Kutub al-Ilmiyah, t.th), Jilid II, h 140. 
hadis no., 4741, 4812, 4813, Bab Khiyal, no. 6453, 6455, dan 6456, Shahih Muslim, Kitab al-Nikah, no. 2543, Sunan Al-Tirmidzi, no. 1025, Sunan al-Nasa'i, Kitab al-Nikah, no 3213, Musnad Ahmad bin Hanbal, Musnad Bani Hasyim, no.1799, Baqi Musnad alMuktsirin bab Abi Hurairah, no. 1799, 6834, 7909, 7433, 9127, dan 17057, Sunan Ibn Majah, al-Nikah, no. 1861, dan 1862, dan Sunan al-Darimi, al-Nikah, no. 2091.

Shahih Bukhari, no. 6455

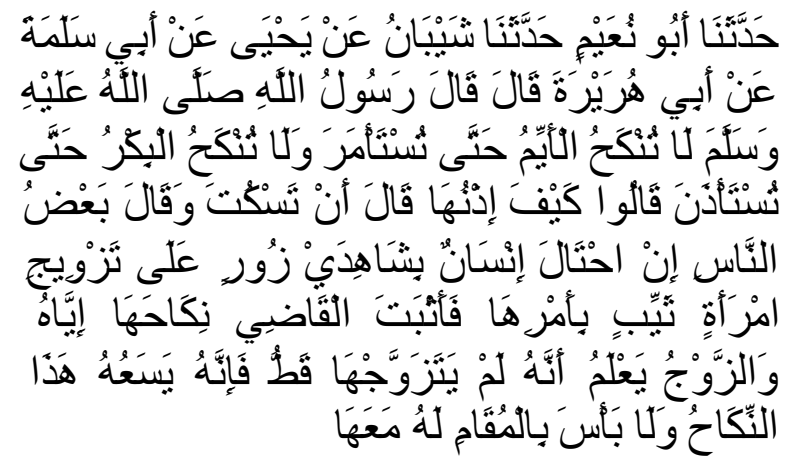

Sunan Al-Tirmidzi, no. $1025^{7}$

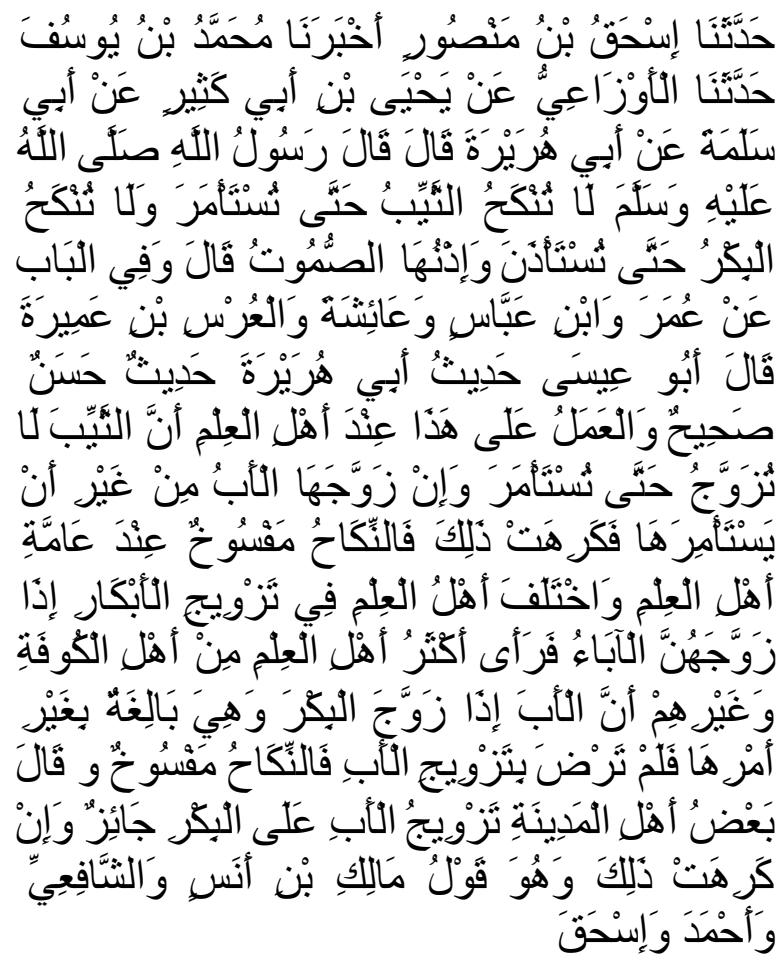

7 at-Tirmidzi, Abu Isa Muhammad ibn Musa ibn al-Dahhaq al-Sulami, Sunan at-Tirmidzi, Berut:Dar al-Kutub al-Ilmiyah,1987), Juz IV, h. 416.
Hadis-had is tersebut berdasarkan penelitian ulama dikategorikan sebagai hadis yang sahih.

\section{Tinjauan Hadis Secara Umum}

\section{Pemaknaan Hadis}

Baik Al-Quran maupun hadis tidak menjelaskan makna ijbar secara rinci, namun diperlukan penjelasan etimologis dengan menelusuri makna kata-kata yang berkaitan dengan masalah ijbar.

Pengertian ijbar muncul dalam bentuk konsep utuh, dan makna yang sebenarnya secara implisit akan tampak kemudian dalam penelusuran konsep tersebut karena kata ijbar mempunyai arti yang dikenal umum dalam bahasa Arab.

Secara etimologis kata Ijbar berasal و الزمه أكرهه .أجبر "ari kata dasar "ajbara" yang berarti "memaksakan dan mewajibkan untuk melakukan sesuatu". Pengertian ijbar berdasarkan kata dasarnya

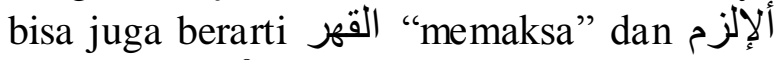
"pemaksaan". 9

Sementara itu secara terminologis ijbar adalah kebolehan bagi ayah atau kakek untuk menikahkan anak perempuan yang masih gadis tanpa izinnya. Dengan demikian ayah lebih berhak terhadap anaknya yang masih gadis dari pada diri anak itu sendiri. ${ }^{10}$ Dalam pengertian fiqh, ayah atau kakek dapat menikahkan anak perempuannya tanpa dibutuhkan persetujuan dari yang bersangkutan, yaitu perempuan yang masih gadis atau atau yang keperawanannya hilang bukan akibat hubungan seksual misalnya karena terjatuh, kemasukan jari dan semacamnya.

Ijbar perlu dibedakan dengan ikrah. Ikrah adalah tindakan yang tidak bertanggung jawab, melanggar hak asasi manusia, dan ter-

${ }^{8}$ Louis Ma'luf, al-Munjid Fi al-Lugat Wa alA'lam, ( Beirut : Dar Al-Masyrik 1968), h. 78

9 Ahmad Warson Munawir, Kamus al-Munawir , (Surabaya: Pustaka Progresif, 1997), h. 164-165

10 Abi Abdillah Muhammad bin Idris AsySyafi'i, al-Umm, (ttp: tnp. tt,), jilid V, h.162-163. Hal itu dengan alasan bapak atau kakek tidak diragukan kasih sayangnya, Sayyid al-bakri ibn al-Arif Billah Muhammad Syatha Ad-Dimyati, I'anatu at-Talibin.. (Semarang: Toha Putera, tt.), Juz IV, h. 53. 
kadang disertai dengan ancaman. Pemaksaan ini dilakukan oleh orang-orang yang diragukan tanggung jawabnya terhadap si gadis. Sedangkan ijbar adalah tindakan untuk melakukan perkawinan bagi anak gadisnya atas dasar tanggung jawab yang hanya bisa dilakukan oleh ayah atau kakek. Ijbar dimaksudkan sebagai bentuk perlindungan atau tanggung jawab seorang ayah terhadap anaknya. Karena keadaan anaknya yang dianggap belum atau tidak memiliki kemampuan atau teman untuk bertindak. ${ }^{11}$ Sementara itu wacana yang berkembang dalam tradisi masyarakat kita adalah bahwa orang tua seringkali memaksa anaknya untuk kawin atau menikahkan anaknya dengan pilihannya, bukan pilihan anaknya, yang populer dengan sebutan kawin paksa. Dalam masyarakat seringkali hukum ijbar dalam fiqh dijadikan legitimasi kewenangan seorang ayah menikahkan anak gadisnya dengan paksa. Hal ini merupakan kesalahan mendasar dalam memahami makna ijbar dan ikrah.

Dengan memahami makna ijbar, kekuasaan seorang ayah untuk menikah anak perempuannya hanyalah hak mengawinkan saja, bukan tindakan memaksakan kehendaknya sendiri tanpa memerhatikan kerelaan sang anak. Dengan demikian hak ijbar seorang ayah lebih menekankan aspek tanggung jawab, dengan asumsi dasar bahwa anak perempuannya belum atau tidak memiliki kemampuan untuk bertindak sendiri.

\section{Pengertian Wali}

Konsep ijbar yang diambil dari doktrin agama melahirkan konsep perwalian yang dikenal dengan istilah wali mujbir. Karena suatu kata kadang memiliki banyak arti, seringkali terjadi kesimpangsiuran pengertian atau pemahaman terhadap kata tertentu. Kata "wali" di kalangan masyarakat muslim mengandung beragam pemahaman. Kata "wali" memiliki makna yang berbeda sesuai dengan bidang dan disiplin keilmuannya. Misalnya, pengertian "wali" menurut pemahaman ilmu

11 Husein Muhammad, Fiqh Perempuan Refleksi Kyai Wacana Agama dan Jender, cet. ke- 2, (Yogyakarta:LKIS, 2002), h. 80. tasawuf akan berbeda dengan pengertian menurut ilmu fiqh.

Menurut Burgerlijk Wetboek, wali ialah orang yang menurut hukum menggantikan anak yang belum dewasa dalam melaksanakan kewajiban yang tergolong perbuatan hukum. ${ }^{12}$ Sedangkan perwalian yang dimaksud dalam istilah fiqh ialah penguasaan penuh yang diberikan oleh agama kepada seseorang untuk melakukan, menguasai dan melindungi orang atau barang. Penguasaan dan perlindungan disebabkan oleh:

1. Pemilikan orang atas orang atau barang, seperti perwalian atau budak yang dimiliki atau barang-barang yang dimiliki.

2. Hubungan kerabat atau keturunan, seperti perwalian seseorang atas salah seorang kerabatnya atau anakanaknya.

3. Karena memerdekakan budak, seperti perwalian seseorang atas budakbudak yang telah dimerdekakannya.

4. Karena pengangkatan, seperti perwalian seseorang kepala negara atas rakyatnya atau perwalian seorang pemimpin atas orang-orang yang dipimpinnya. $^{13}$

'Alauddin al-Khurafa' menjelaskan bah wa secara bahasa perwalian dalam syariah Islam berarti "pertolongan" dan "bantuan" atau "orang yang mempunyai tanggungjawab untuk melaksanakan urusan orang lain, dan menguasai serta mengurusi perkara orang lain tersebut". Sedangkan perwalian menurut istilah adalah "suatu hak untuk mengucapkan suatu ucapan (akad) atas orang lain baik ia menghendakinya atau tidak, dikarenakan kelemahan yang dimiliki oleh orang lain tersebut dan minimnya keahlian untuk melakukan

12 Djohan Effendi, "Wali', dalam Ensiklopedi Nasional Indonesia, (Jakarta:PT Cipta Adi Pustaka, 1991), XVIII: 232.

13 Kamal Muchtar, Asas-asas Hukum Islam Tentang Perkawiann, cet. ke- 3, (Jakarta: Bulan Bintang, 1993), h. 93 Oleh sebab itu secra garis besar perwalian itu dapat dibagi atas, Perwalian atas orang, Perwalian atas barang, dan Perwalian atas orang dalam perkawinan 
transaksi atas dirinya sendiri". ${ }^{14}$ Sedangkan menurut Abd al-Rahman al-Jaziri wali dalam pernikahan adalah orang yang menentukan sahnya suatu akad, dan akad tidak sah hukumnya bila dilakukan oleh selain dia. Adapun wali tersebut adalah ayah dan wali alqarib, al-asib, orang yang memerdekakan dan penguasa. ${ }^{15}$

\section{Perbedaan Pengertian Antara Bikr dan Tsayyib}

Dalam wilayah ijbar, terdapat pemaknaan yang berbeda antara perempuan $b i k r$ dan tsayyib sehingga implikasi hukum terhadap keduanya juga berbeda. Yang dinamakan $b i k r$ adalah perempuan yang masih perawan, yakni sebutan untuk perempuan yang benar-benar belum pernah berhubungan seksual. ${ }^{16}$ Adapun yang disebut dengan $b i k r$ hakikah yakni siapa saja yang hilang kegadisannya karena melompat, kuatnya haid, atau karena terluka dan perempuan yang menikah dengan akad yang sahih atau fasid, tetapi diceraikan oleh suaminya atau suaminya meninggal sebelum bercampur, dan hilang kegadisannya karena zina, hukumnya seperti gadis. ${ }^{17}$ Sedangkan tsayyib adalah seorang perempuan yang tidak lagi perawan dan keperawanannya hilang karena hubungan seksual yang sah. ${ }^{18}$

\section{Analisis Historis Konsep Ijbar}

Dalam Al-Quran tidak ada dalil yang secara khusus atau langsung merujuk pada persoalan hak ijbar, tetapi yang disinggung dan ditekankan dalam Al-Quran adalah kewajiban wali dalam menikahkan anak perempuan. Al-Quran mencatat larangan memper-

14 'Alauddin al-Khurafa', Syarh Qanun alAhwal asy-Syakhsiyyah, (Bagdad: Matba'ah al-Aniy, 1962), jilid I, h. 189.

15 Abdurrahman al-Jaziri, Kitab al-Fiqh Ala Mazahib al-Arba'ah, (Mesir: al-Tijariyyah al-Kubra, 1969), jilid VI, h. 26

16 Al-Malibari, Fathu al-Muin, t.tp: an- Nasyir Syirkah Asia, tt h.103. IV, h. 32

7 Abdurrahman al-Jaziri, Kitab al-Fiqh..., jilid

18 Muhammad Najib al-Mut'i, al-Majmu' Ala Syarh al-Muhazab, (Mesir: al-Imam, tt.), III, h. 221. sulit pernikahan wanita. ${ }^{19}$ Adapun dasar kebolehan ayah dan kakek menikahkan perempuan tanpa izin dari yang bersangkutan adalah hadis dari Aisyah, bahwa boleh bagi ayah dan kakek menikahkan anak gadis tanpa kerelaannya.
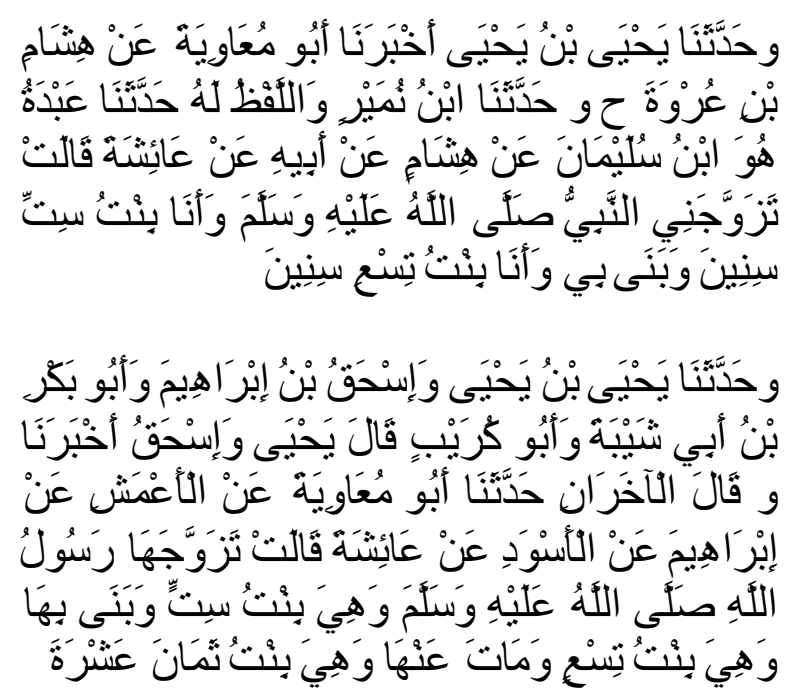

Kedua hadis di atas ${ }^{20}$ berbeda mengenai usia A'isyah ketika dinikahkan dengan $\mathrm{Mu}-$ hammad SAW.; hadis pertama mengatakan ketika itu 'Aisyah berumur 16 tahun dan mengadakan hubungan setelah 'A isyah berusia 19 tahun, sedangkan hadis kedua adalah pada usia 6 atau 7 tahun, dan mengadakan hubungan setelah berusia 9 tahun. Tindakan Abu Bakar yang menikahkan anaknya yang belum dewasa ini, ditambah dengan alasan bahwa semua urusan anak kecil merupakan tanggung jawab ayahnya, dijadikan landasan oleh Syafi'i untuk menetapkan adanya hak ijbar ayah bagi anaknya yang belum dewasa, dengan catatan gadis berhak memilih (khiyar) kalau sudah dewasa. ${ }^{21}$

Kebolehan seorang ayah menikahkan anak gadis di bawah umur 15 tahun didasarkan pada argumentasi bahwa jihad boleh

19 QS.Al-Baqarah (2): 232.

${ }^{20}$ Muslim, Sahih..., jilid I, h 141, H.R. Yahya bin Yahya dari 'Aisyah. Hadis semakna dengan lafaz berbeda terdapat dalam Ahmad bin Ali bin Hajar alAsqalani, Fath al-Bari, (ttp: al-Maktabah as-Salafiyah, tt.), IX: 224. H.R. Qubaidah bin Uqbah dari 'Aisyah. (CD Mausu;ah hadis no. 2546 \& 2547),

${ }^{21}$ Imam asy-Syafi' i, al-Umm...opcit, jilid V, h. 16. 
dilakukan pada usia tersebut. Al-Quran surat al-Nisa: 6 menyebutkan "Dan ujilah anakanak yatim itu sampai mereka mengerti atau dewasa, maka serahkanlah kepada mereka hartanya," 22 karena itu seorang anak gadis itu hanya mengelola urusannya setelah berusia 15 tahun.

Hadis-hadis diatas lebih banyak memberikan pengertian bahwa diamnya perempuan merupakan tanda kesepakatan seorang gadis untuk dinikahkan. Bunyi hadis itu selaras dengan setting historisnya dan dengan kehidupan serta kondisi psikologis kaum perempuan saat itu. Budaya patriarkhi saat itu sangat melekat pada masyarakat, dimana kaum perempuan masih berkiprah di "pekarangan rumah", sehingga mereka sulit untuk mengungkapkan perasaannya secara terbuka. Perempuan cenderung memusatkan perhatian pada menyelaraskan diri dengan nilai dan norma yang berlaku.

Hadis lain yang dijadikan dasar kebolehan ayah dan kakek menikahkan anak perempuannya tanpa persetujuan dari yang bersangkutan adalah faham sebaliknya (mafhum mukhalafah) dari hadis yang diriwayatkan oleh Ibn Abbas yang berbunyi. ${ }^{23}$

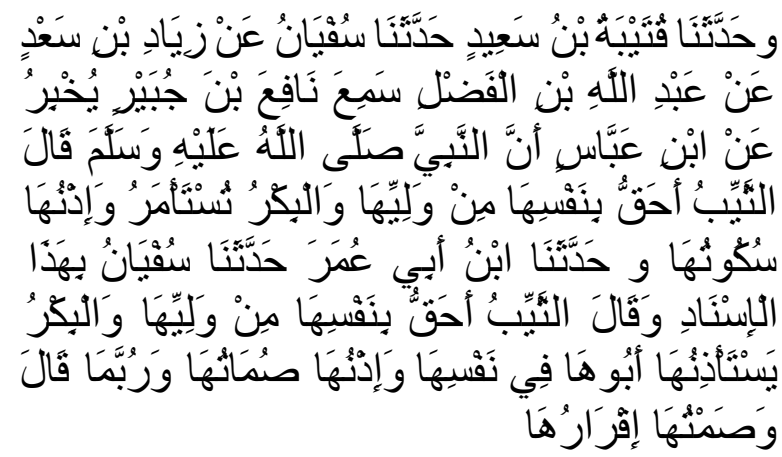

Hadis tersebut dijadikan dasar tentang hak berimbang antara ayah dan anak. Hak ayah didasarkan atas mafhum mukhalafah hadis tersebut bahwa ayah lebih berhak menentukan urusan perkawinan anak gadisnya. Meskipun dianjurkan agar kedua belah pihak

22 Ibid., h. 18
23 Muslim, Sahih..., h 594, H.R. Sa'id bin Mansur dan Qutaibah dari dari Ibnu Abbas. Hadis semakna dengan lafaz berbeda terdapat dalam, atTirmizi, jilid II, h. 286, H.R. Qutaibah dari Ibnu Abbas bermusyawarah, hukum menetapkan izin ayah pada anak gadis sebagai sebuah anjuran kebaikan semata.

Ulama yang menyetujui adanya ijbar tidak berhujjah dengan hadis lain yang menjelaskan bahwa dalam perkawinan hendaknya meminta persetujuan terhadap mempelai perempuan, meskipun hadis semacam itu sangat banyak dibandingkan hadis yang dijadikan sebagai landasan ijbar.

\section{Proyek Pemikiran Ulama \\ Dasar Hukum Wali}

Dalam mazhab Syafi' $i$, wali dalam pernikahan menjadi sesuatu yang harus ada, karena wali nikah adalah termasuk salah satu rukun nikah, yang berarti pernikahan tanpa seorang wali tidak sah hukumnya. ${ }^{24}$

\section{a. Keharusan wali dalam pernikahan}

Dasar hukum penetapan wali adalah Al-Quran dan sunah. Al-Quran menyatakan:

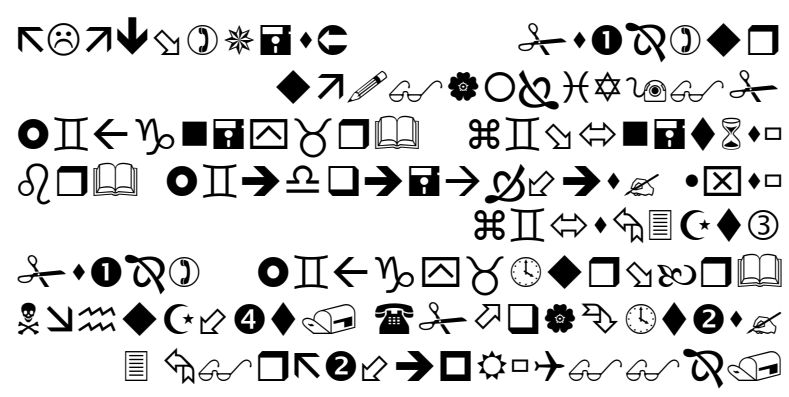

Apabila kamu mentalak istrinya-istrimu lalu habis masa iddahnya, maka janganlah kamu (para wali) menghalangi mereka kawin lagi dengan bakal suaminya apabila telah terdapat kerelaan diantara mereka dengan cara yang ma'ruf. (QS. 2: 232)

Ulama berbeda pendapat tentang khitab ayat tersebut. Pendapat pertama menyatakan bahwa ayat tersebut turun pada peristiwa Ma'qal ibn Yasar, yang mencegah saudara

${ }^{24}$ Rukun nikah menurut mazhab Syafi' iyah ada lima yaitu; 1. Suami. 2. Isteri. 3. Wali. 4. Dua orang saksi. 5. Sigat akad. Zainuddin bin Abdul Azis alMalibari, Fathu al-Mu'in, (ttp: an-Nasyir Syirkah Asia , tt.), h. 99; Syarat seorang walipun diperketat dengan memenuhi persyaratan, Is lam, baligh, berakal, merdeka, lelaki dan adil, Taqiyyuddin Abi Bakri bin $\mathrm{Mu}-$ hammad al-Husaini al-Husni ad-Dimasyqi asy-Syafi' i, Kifayatu al-Akhyar Fi Halli Gayah al-Ikhtisar, (ttp: Dar al-Fikr,tt.), h. 49 
perempuannya untuk kembali rujuk dengan suami pertamanya, al-Barrah Abdullah ibn 'Asim. Ayat tersebut turun sebagai petunjuk bahwa perempuan tidak boleh menikahkan dirinya sendiri dan larangan para wali untuk menolak menikahkan perempuan. ${ }^{25}$

Pendapat kedua menyatakan bahwa khitab ayat tersebut ditujukan kepada para suami yang telah menceraikan isterinya dan habis masa iddahnya, kemudian ia mempersulit untuk menikah dengan laki-laki lain. ${ }^{26}$

Menurut ulama Syafi'iyah turunnya ayat tersebut adalah untuk menunjukan ketidakbenaran tindakan wali yang mencegah perkawinan. Oleh karena itu, kasus tersebut menunjukan keharusan akan adanya wali dalam perkawinan. ${ }^{27}$ Dengan kata lain, kalau memang wanita boleh menikahkan diri sendiri tanpa adanya wali, maka untuk apa ayat ini turun. Maksud ayat ini adalah untuk menunjukkan keharusan adanya wali dalam perkawinan dan sekaligus larangan bagi perempuan untuk menjadi wali nikah. ${ }^{28}$

Menurut ulama Syafi'iyah tunjukan (khitab) ayat ini adalah pada para wali. Berbeda dengan pandangan ini, menurut Hanafiyah tunjukan ayat ini bukan kepada para wali, tetapi kepada suami yang menceraikan isteri kemudian menahan agar tidak dinikahi laki-laki lain. ${ }^{29}$

Sedangkan hadis yang mengharuskan wali dalam pernikahan adalah sejumlah hadis berikut; pertama, hadis riwayat Tirmidzi dari Abu Musa bahwa "tidak ada pernikahan tanpa wali". Menurut al-Dimasyqi hadis ini sahih dan bahkan menurut Ibn Mu'in hadis ini adalah termasuk yang paling sahih di an-

25 Ismail Haqqiy al-Bursawi, Tafsir Ruh alBayan, (Beirut : Dar al-Fikr, tt.), jilid I, h. 361

26 Ibid.; juga Nasiruddin Abi Sa'id Abdullah bin Umar bin Muhammad asy-Syirazi al-Baidawi, Tafsir Baidawi, (ttp: Dar al-Fikr, tt.), jilid I, h. 243.

27 Abu Hasan Ali bin Muhammad bin Habib alMawardi, an-Nuktu Wa al-'Uyun Tafsir al-Mawardi, (Beirut: Dar al-Kutub al-Ilmiyyah tt.) I: 298.

28 Ad-Dimasqi, Kifayatu al-Akhyar, h. 48; Sayyid al-Bakri ibn al- Arif Billah Muhammad Syatha ad-Dimyati, I'anatu al-Talibin, (Semarang: Taha Putra, tt.), jilid II, h. 307.

29 Syamsuddin asy-Syarakhsi, al-Mabsut, (ttp: Dar al-Fikr, tt.), V: 11-12. tara hadis yang berbicara tentang keharusan wali dalam perkawinan. kedua, hadis riwayat dari Abu Hurairah yang menyatakan bahwa "seorang perempuan tidak boleh menikahkan perempuan lain atau menikahkan dirinya sendiri". Hadis tersebut menyatakan keharusan adanya wali dalam pernikahan. hal tersebut bertujuan untuk menutupi kekurangan perempuan yang kurang akal (emosional) dan cepat tertipu. ${ }^{30}$

Adapun hadis yang melarang perempuan menjadi wali nikah, selain hadis-hadis di atas, adalah hadis yang menyatakan bahwa bila seorang perempuan tidak memiliki wali nasab, maka ia dapat menggantikannya dengan wali hakim.

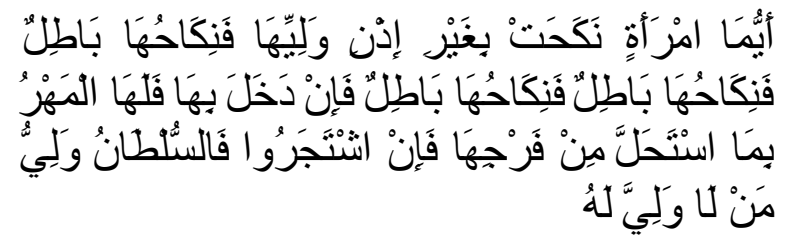

Menurut al-Dimyati, pendapat yang melarang seorang wanita menikahkan diri sendiri dan bahwa ia tidak berhak menjadi wali nikah adalah pendapat yang kuat, sebab pendapat ini ditopang oleh hadis-hadis sahih, dan isinya juga dikuatkan oleh had is lain. ${ }^{31}$

Abd al-Rahman al-Jaziri membagi perwalian menjadi dua, yaitu;

1. Wali mujbir yang baginya hak untuk menikahkan orang yang berada di bawah perwaliannya tanpa meminta izin atau kerelaan mereka.

2. Wali ghair mujbir yang tidak mempunyai hak sebagaimana wali $m u j$ bir, dan tidak ada hak baginya untuk menikahkan tanpa izin. ${ }^{32}$

Mengenai urutan atau tingkatan para wali, para ulama fiqh berbeda pendapat. Menurut Malik, wali yang pertama ialah anak laki-laki, kemudian ayah, saudara seibu seayah, saudara seayah, anak-anak saudara seibu

30 Abu Ishaq Ibrahim bin Ali Ibnu Yusuf alFairu zzabadi asy- Sy irazi, al- Muhazzab Fi Fiqhi alImam asy-Syafi'i, (ttp: Dar- al- Fikr. tt.), jilid II, h 35.

31 Ad-Dimyati, op.cit, jilid III, h. 307.

32 Abdurrahman al-Jaziri, Kitab Fiqh..., jilid IV, h. 28 . 
dan seayah lalu anak-anak saudara seayah baru kemudian kakek dari ayah, paman (menurut tertib saudara), kemudian maula dan sesudah itu sultan. Adapun perwalian ayah harus didahulukan atas perwalian lain.

Sebagaimana disebutkan bahwa kedudukan wali dalam pernikahan adalah sebagaimana syarat sahnya, merupakan pendapat di kalangan ulama fiqh. Al-Syafi'i berpendapat bahwa wali merupakan syarat dalam pernikahan seorang perempuan, tidak sah akad tanpa adanya wali, dan tidak ada hak bagi perempuan untuk melakukan akad atas dirinya sendiri meskipun perempuan tersebut telah diizinkan oleh walinya baik perempuan itu masih anak-anak atau sudah dewasa, mulia atau hina, perawan atau janda.

Syafi'i berbeda dengan Malik dalam soal mendahulukan saudara daripada kakek dan dalam hal wali anak, karena Syafi' $i$ tidak membenarkan adanya wali anak. Dalam susunan yang lain Syafi'i sepaham dengan Ahmad dengan Malik. Ahmad juga sepaham dengan Malik, hanya saja Ahmad mengutamakan ayah atas anak. ${ }^{33}$

Pengikut Syafi'i sepakat bahwa illat pernikahan ijbar atau perwaliannya adalah kegadisan, sementara menurut Abu Hanifah illat pernikahan ijbar adalah usia gadis yang belum baligh. Perwalian bersifat tetap hingga perempuan tersebut dewasa atau baligh selama masih dalam keadaan gadis. Hal itu dikarenakan anak gadis dipandang belum memahami kemaslahatan dalam pernikahan dan belum mengetahui karakter kaum laki- laki.

Adapun yang dimaksud dengan gadis adalah perempuan yang belum hilang kegadisannya dan menyerupai gadis di dalam hukumnya. Termasuk ke dalam kategori perempuan yang menyerupai gadis adalah mereka yang diciptakan tanpa kegadisan atau hilangnya kegadisan tanpa persetubuhan, misalnya karena terjatuh, kuatnya haid, masuknya jari dan persetubuhan melalui dubur. ${ }^{34}$ Pernikahan ijbar dipandang sah jika gadis tersebut

33 Hasbi ash-Shiddieqy, Hukum-hukum Fiqh Islam, cet. I, (Jakarta: Bulan Bintang, 1960), h. 235.

34 Berbeda dengan Imam Abu Hanifah bahwa illat pernikahan ijbar adalah anak kecil, ad-Dimasyqi, op.cit, h 53. dinikahkan dengan suami yang sekufu dan mampu memberi nafkah. Namun jika dinikahkan dengan suami yang tidak sekufu dan tidak mampu memberi nafkah maka pernikahan tersebut tidak sah. ${ }^{35}$

\section{b. Syarat-syarat hak ijbar}

Berbeda dengan wali lain, seorang ayah mempunyai hak mengawinkan anak gadisnya dengan seorang suami yang dipandang dapat membahagiakannya tanpa keharusan meminta persetujuan anaknya terlebih dahulu.

Menurut Syafi'iyah, terdapat beberapa syarat yang harus dipenuhi dalam hak ijbar:

1. Yang boleh menikahkan anak gadis secara ijbar hanyalah ayah dan kakek dari mempelai perempuan sendiri. Alasannya ialah seorang ayah dan kakek tidak diragukan lagi kasih sayangnya. Wali lain selain ayah dan kakek tidak berhak melakukan $i j b a r .^{36}$

2. Orang tua yang melakukan ijbar terhadap anak gadis tidak mempunyai permusuhan atau kebencian. Ijbar hanya dilakukan oleh ayahnya berdasarkan kasih sayang dan kepedulian yang tulus terhadap masa depan anak gadis. Bila ada perselisihan antara wali dan anak gadisnya, maka yang menjadi wali nikah adalah sultan (penguasa). ${ }^{37}$

3. Calon suami harus setara, baik dalam tingkat sosial, pendidikan, perekonomian atau keturunan, supaya terdapat keharmonisan dalam kehidupan mereka. Menurut mazhab Syafi'iyah, kesetaraan yang dimaksud adalah dalam urusan agama, keturunan, kemerdekaan dan pekerjaan. $^{38}$

4. Maskawin yang dijanjikan oleh calon suami harus mahar mitsl, yakni

35 Ibid, h. 103.

36 Syarat-syarat ijbar ini diterangkan secara lengkap dalam kitab Iqna'. Lihat, Muhammad asySyarbini al-Khatib, al-Iqna' Fihalli al-Fazi Abi Syuja 'i, (Semarang: Toha Putera, t.t.), jilid II, h. 128.

37 Asy-Syirazi, al-Muhazzab, II, h. 37.

38 Ibid, II, h..39. 
maskawin yang sesuai dengan martabat dan kedudukan sosial perempuan.

5. Calon suami adalah orang yang sanggup memenuhi kewajiban nafkahnya. Seorang ayah boleh menikahkan anak gadisnya apabila pernikahan tersebut tidak merugikan anak gadisnya. ${ }^{39}$

6. Calon mempelai laki-laki diketahui sebagai orang baik-baik dan akan memperlakukan isterinya secara baik pula.

Ketentuan ijbar diiringi anjuran untuk bermusyawarah dengan pihak-pihak yang hendak melangsungkan pernikahan dalam rangka mendapatkan izin atau persetujuan dari yang bersangkutan. Menurut Syafi ${ }^{\prime} i$, terhadap pertanyaan mengapa harus bermusyawarah dengan seorang anak gadis, sebagaimana firman Allah:

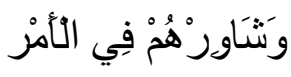

maka sesungguhnya Allah mewajibkan atas anak gadis untuk bersikap taat, akan tetapi dalam musyawarah itu terdapat kebaikan bagi mereka. ${ }^{40}$

Mengenai kebebasan dan persetujuan kaum wanita dalam perkawinan al-Syafi' $i$ mengk lasifikasikannya ke dalam tiga kelompok: pertama, gadis yang belum dewasa; kedua, gadis dewasa; dan ketiga, janda. ${ }^{41}$ Untuk gadis yang belum dewasa, batasan umurnya adalah di bawah 15 tahun atau belum keluar darah haid. Dalam hal ini seorang ayah boleh menikahkan gadis tersebut tanpa izinnya terlebih dahulu (hak ijbar), selama pernikahan tersebut tidak merugikan sang anak. Dasar penetapan hak ijbar ini adalah tindakan Nabi yang menikahi Ais yah ketika masih berusia 7 tahun dan mengadakan hubungan setelah 9 tahun, dan tindakan Abu Bakar yang menikahkan anaknya yang masih belum dewasa

39 Imam asy-Syafi'i, al-Umm, V: 16-17; alMalibari, Fathu al-Mu'in, h. 103.

${ }^{40}$ Imam asy-Syafii, al-Umm..., jilid V, h 19.

41 Khoiruddin Nasution, "Peran Wali Nikah dan Kebebasan Wanita", Makalah PSW IAIN Sunan Kalijaga, (Yogyakarta:PSW IAIN Yogyakarta), h. 12. ini, dengan alasan bahwa semua urusan anak kecil merupakan tanggung jawab ayahnya. ${ }^{42}$

Mengenai perkawinan seorang anak gadis yang sudah dewasa, terdapat hak berimbang antara ayah dengan anak gadisnya. Hak ayah didasarkan atas prinsip mafhum mukhalafah dari hadis yang menyatakan bahwa janda lebih berhak kepada dirinya. Mafhum mukhalafah hadis ini adalah ayah lebih berhak menentukan urusan perkawinan anak gadisnya, meskipun ada anjuran untuk bermusyawarah diantara kedua belah pihak. Dari penjelasan itu dapat diambil kesimpulan bahwa hak ayah melebihi hak anak gadisnya baik yang sudah dewasa maupun yang belum dewasa. ${ }^{43}$

Adapun perkawinan seorang janda harus ada izin secara tegas dari yang bersangkutan. Keharusan ini didasarkan pada kasus perkawinan yang ditolak karena seorang janda dikawinkan seorang wali dengan seorang yang tidak disenangi dan tidak dimintai persetujuannya terlebih dahulu. Hal ini terjadi pada kasus Khunsa'a bint Khadam, al-Ansariyati, seorang janda yang dinikahkan oleh ayahnya tanpa seizinnya, sehingga ia mengadukan kepada Rasulullah yang kemudian membatalkan perkawinan itu. ${ }^{44}$ Dengan demikian, seorang janda lebih berhak terhadap dirinya sendiri daripada walinya, dan validitas perkawinannya bergantung pada persetujuannya, dan tidak ada orang lain yang berhak mencegahnya untuk menikah sebagaimana yang tergambar pada hadis berikut:

Khunsa'a melapor kepada Nabi ketika ia dinikahkan ayahnya dengan anak saudara ayahnya yang tidak ia senangi, Nabi balik bertanya, "Apakah kamu dimintakan ijin (persetujuan)?" Jawab Khunsa'a, "Saya tidak senang dengan pilihan ayah." Lalu Nabi menyuruhnya pergi, kemudian menetapkan sebagai perkawinan yang tidak sah, seraya bersabda "Nikahlah dengan orang

42 Imam asy-Syafii, al-Umm..., jilid V, h 15.

43 Husein Muhammad, Refleksi Kiai ..., h. 80.

44 Hal ini terjadi pada kasus Khansa'a binti Khadam, al-Ansariyati, bahwa ia seorang janda yang dinikahkan oleh ayahnya tanpa seijinnya namun ia tidak menyukainya, lalu ia mengadukan kepada Rasulullah kemudian beliau menolak perkawinan itu. Asy-Asyirazi al-Muhazzab...., h. 37. 
yang kamu senangi.” Khunsa'a berkomentar, "Bisa saja aku menerima pilihan ayah tetapi aku ingin agar para wanita mengetahui bahwa ayah tidak berhak memaksakan kehendaknya untuk menikahkan anak putrinya, dan menyetujuinya." Ditambah lagi oleh Khunsa'a Nabi tidak minta keterangan apakah saya gadis atau janda. ${ }^{45}$

Kasus Khunsa'a ini menjadi salah satu dalil tidak adanya perbedaan antara gadis dan janda tentang keharusan akan adanya persetujuan dari yang bersangkutan dalam perkawinan.

Ketentuan persetujuan pernikahan dalam wilayah ijbar menurut konsep mazhab Syafi'i tersebut sangat berbeda dengan konsep menurut mazhab Abu Hanifah. Menurut Abu Hanifah persetujuan dari anak perempuan adalah satu keharusan dalam perkawinan, baik ia seorang gadis maupun janda. Jika persetujuan gadis cukup dengan diamnya, persetujuan seorang janda harus dinyatakan secara tegas. Ijbar hanya diberlakukan terhadap wanita di bawah umur, bukan terhadap perempuan yang sudah dewasa (balighah akilah).

Sedangkan menurut ulama Hanafiyah, keharusan adanya persetujuan gadis dalam perkawinan disandarkan pada contoh dari Nabi yang menolak pernikahan seorang gadis yang dinikahkan ayahnya sementara gadis itu sendiri tidak menyetujuinya, dan pada hadis yang menyebutkan bahwa seorang wali boleh menikahkan gadis dengan syarat sang calon setuju dengan perkawinan tersebut, yang ditandai dengan diamnya, tetapi kalau gad is itu menolak maka ia tidak boleh dipaksa. ${ }^{46}$

Dengan demikian, maka dapat disimpulkan bahwa para ulama memiliki pandangan dan penetapan hukum yang varian terhadap implementasi konsep ijbar dalam pernikahan.

\section{Proyeksi Realitas Konsep Ijbar}

Pandangan ulama terdahulu berbeda apabila dibandingkan dengan kaum Islam modernis yang cenderung terfokus hanya kepada

\footnotetext{
45 Ibid.

${ }^{46}$ Asy-Syarakhsi, al-Mabsut...op.cit,V: h. 2
}

al-Quran dan Hadis, dengan menolak otoritas fiqih dan mazhab. ${ }^{47}$ Para ulama modernis dalam kadar tertentu memperbolehkan penggunaan penalaran rasional, sementara ulama tradisionalis cenderung selama masih memungkinkan kepada penerapan harfiyah hukumhukum fiqh yang ditetapkan para ulama besar di masa lalu. ${ }^{48}$

Dari hal tersebut diatas, tampak bahwa pola dasarnya menggunakan pola pemikiran ahl al-hadits dan bukan ahl al-ra'y. Pola pemikiran pertama dimaksudkan sebagai cara dan kecendrungan dalam mengkaji dan menyelesaikan suatu persoalan dengan lebih memperhatikan aspek lahiriyah dan riwayat suatu teks ${ }^{49}$. Ahl al-hadits membela otoritas teks-teks keagamaan dan kekuasaanya atas setiap bidang aktifitas kemanusiaan. Teks dengan berbagai cara mampu memecahkan setiap problematika atau peristiwa yang telah terjadi atau mungkin terjadi pada saat ini atau masa depan. ${ }^{50}$ Sementara itu aspek rasional (manath al-amr) sebagaimana menjadi kecendrungan pola kedua (ahl al-ra'y) kurang banyak diperhatikan. Lebih dari itu, upayaupaya menuju pertimbangan sosiologis dimaksudkan sebagai kajian latar belakang sosial-budaya, ihwal mengapa suatu teks lahir sebagaimana termaktub. Persoalan ini sesungguhnya menjadi signifikan ketika kita bermaksud mengembangkan pemikiran teks untuk konteks yang berbeda. ${ }^{51}$

47 Robin. 1. Bush, "Wacana Perempuan di Lingkungan NU, Sebuah Perdebatan Mencari Bentuk “, dalam Taswirul Afkar, Ed. No.5.Th.1999, h.29.

${ }^{48}$ Martin Van Bruinessen, NU: Tradisi, RelasiRelasi Kuasa, Pencarian Wacana Baru, (yogyakarta: LkiS, 1994), h. 212

${ }^{49}$ Hus ein Muhammad, "Kontekstualisasi Kitab Kuning”. dalam Pesantren Masa depan. h.272.

${ }^{50}$ Nasr Hamid Abu Zaid, alih bahasa; Khoiron Nahdliyyin, Imam Syafii: Moderatisme, Eklertisme, Arabisme, (Yogyakarta: Lkis, 1997), h. 48.

51 Husein Muhammad, Kontekstualisasi...., h. 272. Perlu adanya pendekatan Hermeneutik terhadap hadis, hal ini untuk membedakan hadis-hadis membawa konsekuensi pada hukum (legal character) dan hadis-hadis yang tidak membawa konsekuensi hukum (non legal character). Sehingga setting hitoris harus diperhatikan, sejauh mana hadis hukum-hukum tersebut yang mengandung unsur peradaban, sosiokultural dan hukum secara kontektual. Lihat Muham- 
Penafsiran mazhab ahl al-hadits ini dilatarbelakangi oleh suatu pandangan yang diyakini bahwa apa yang sudah diputuskan oleh ulama atau qaul faqih dipandang selalu memiliki relevansi dengan konteks kehidupan sekarang dan harus dipakai tanpa reserve apalagi kritik. Qaul ulama yang dikemukakan dalam kitab-kitab rujukan dianggap sebagai kata final. Boleh jadi pandangan demikian juga berkaitan dengan hakikat ilmu itu sendiri. Pada masa lampau ilmu dirumuskan sebagai sesuatu yang diketahui dan diyakini secara tuntas. ${ }^{52}$

Dari sejumlah hadis yang berbicara tentang hak ijbar wali di atas, pada prinsipnya hadis-hadis tersebut menekankan pada pentingnya persetujuan perempuan. Sebaliknya dasar yang digunakan untuk mendukung hak ijbar didasarkan pada mafhum mukhalafah dan dari nash yang menyebutkan bahwa janda lebih berhak atas dirinya, padahal secara tekstual terdapat nash yang menyebutkan harus ada persetujuan dari perempuan yang akan dinikahkan. Sedang makna hadis yang menyatakan bahwa perempuan itu dinikahi ayahnya tidak berarti boleh memaksa.

Dari kajian diatas dapat disimpulkan tidak ada hak ijbar bagi orang tua/kakek pada perempuan gadis ataupun janda yang sudah dewasa (baligh), tetapi harus dengan persetujuannya. Ada satu kisah yang diriwayatkan oleh Siti Aisyah yaitu bahwa:

"Aisyah pernah menceritakan mengenai kedatangan seorang perempuan muda bernama Khunsa bint Khidam al-Anshari, berkata: Ayahku telah menikahkan aku dengan anak saudaranya. Ia berharap dengan menikahkan aku ke lakuan buruknya hilang. Aku sendiri sebenarnya tidak menyukainya. Aisyah berkata: "Kamu tetap duduk di sini sambil menunggu Rasulullah s.a.w.”. Begitu be liau datang ia menyampaikan persoalan tadi. Nabi kemudian memanggil ayahnya, la lu memintanya agar menyerahkan persoalan perjodohan kepada anaknya (anak perempuan itu). Si perempuan kemudian berkata kepada Nabi: "Wahai Rasu-

mad Iqbal, Reconstruction of Religion Though in Islam, (New Delhi: Kitab Bhayan, 1982) hl, 171.

52 Husein Muhammad, Tradisi Istinbat..., h.

67. lullah s.a.w, aku sebenarnya menuruti apa yang telah diperintah ayahku, akan tetapi aku hanya ingin memberitahuka kepada kaum perempuan bahwa sebenarnya para ayah tidak mempunyai hak atas persoalan ini. $^{53}$

Ada riwayat lain yang menjelaskan tentang perempuan dibolehkan memilih antara meneruskan perkawinann atau membatakannya jika dinikahi orang tuanya dengan cara ijbar yaitu:

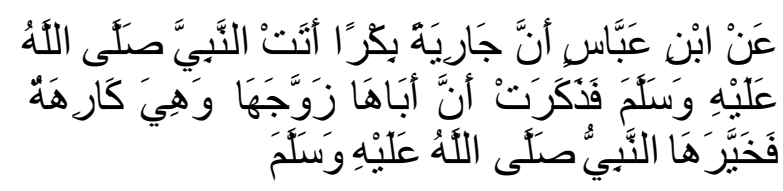

Dari Ibn Abbas, ia berkata: "sesungguhnya seorang gadis telah mengadukan halnya kepada Rasulullah s.a.w bahwa ia telah dinikahkan oleh ayahnya dan di tidak menyukainya. Maka Nabi memberi kesempatan itu untuk memilih (antara meneruskan atau membatalkan pernikahan itu)" (HR. Ahmad, Abi Daud, Ibnu Majah dan Daruquthni)

Menurut ulama Hanafiyah hadis tersebut dijadikan pelarangan ijbar (pemaksaan) bagi ayah maupun wali terhadap anak perempuan atau janda yang sudah dewasa, karena hadis lain menyebutkan untuk meminta persetujuan pada anak perempuan atau janda.

Berkaitan dengan pernikahan gadis di bawah umur, ada pendapat menarik yang dikemukakan oleh Ibn Syibrimah, ${ }^{54}$ katakan: 'mengawinkan anak gadis di bawah umur tidak sah, demi kemaslahatan anak gadis yang bersangkutan, juga keluarga". Pendapat ini memberikan tuntunan rasional bahwa karena yang akan menjalani rumah tangga adalah anak perempuannya maka seorang ayah atau kakek harus memberikan kesempatan kepada anak gadisnya untuk tumbuh dan berkembang menjadi orang yang dewasa yang dapat memilih jalan hidupnya serta menentukan jodoh-

53 Ibnu tsai, Jami' al-Ushul, Juz XII. p.140, hadis nomor 8974

54 Wahbah al-Zuhaili, al-Fiqh Islam Wa Adillatuhu, (Damaskus:Darul Fikr,1989), vol VII, h. 189 
nya. Perkawinan hendaknya dilangsungkan setelah masing-masing mencapai tarap kematangan (maturitas), baik secara fisik-biologis maupun mental-psikologis.

Dari sudut pandang perkawinan dalam undang-undang Perkawinan No. I Tahun 1974, Sebagai hukum positif Indonesia, yang mengatur perkawinan tentang usia pasangan pengantin, bagi laki-laki usia 19 dan perempuan usia 16, kemungkinan kecil ijbar bisa dilaksanakan. Namun hak ijbar masih sering dilakukan oleh masyarakat, maka perlunya memberikan pemahaman baru pada masyarakat bahwa ijbar bukan hak sepenuhnya orang tua. Oleh karena itu, dalam menikahkan anak terdapat hal-hal yang harus diperhatikan:

1. Orang tua membimbing anak-anaknya dengan membekali ajaran agama, dan memberikan wawasan yang luas dalam memilih pasangan hidup nanti, agar benar-benar dipahami secara matang

2. Menikahkan anaknya hendaknya dilangsungkan setelah masing-masing mencapai tarap kematangan, baik secara fisik-biologis maupun mental-psikologis, karena pernikahan dibawah umur bisa mematikan keberlangsungan hid up anak

3. Adanya kompromi dan hubungan atau komunikasi dua arah yang harmonis antar pasangan pengantin maupun antar kedua keluarga pengantin.

\section{DAFTAR PUSTAKA}

Muslim, Abu Husein. tt. Shahih Muslim. Beirut: Dar al-Kutub al-'Ilmiyyah.

al-'Asqalani, Ibn Hajar. tt. Fath al-Bari (jilid IX). ttp: Al-Maktabah al-Salafiyyah.

Baidlawi, Nasiruddin Abi Sa id Abdullah ibn Umar ibn Muhammad al-Syirazi. tt. Tafsir al-Baidlawi (Juz 1). Beirut: Dar al-Fikr.
4. Dalam pernikahan dibutuhkan keikhlasan dan keridhaan dari orang tua dan anak serta keluarga, karena persoalan pernikahan bukan semata persoalan kedua orang tua, akan tetapi merupakan kemaslahatan keluarga, tanpa pemaksaan dan kekerasan

\section{Penutup}

Awal kehidupan keluarga diisi oleh sepasang mempelai melalui jalur pernikahan. Masih ada dalam ingatan kita tentang kisah Siti Nurbaya yang belum bisa terlepas dari tradisi tersebut, yang diakibatkan dari pemahaman yang parsial terhadap teks-teks keagamaan. Konsep ijbar yang dicetuskan ulama terdahulu ternyata jauh berbeda dengan kehidupan sekarang. Memang orang tua tidak akan menjerumuskan anaknya akan tetapi alangkah lebih baiknya jika pilihan pasangan jiwa dalam menempuh hidupnya adanya persetujuan dari keduanya. Bagi kaum perempuan (mungkin juga bisa terjadi pada kaum laki-laki yang dipaksa untuk menikahi pilihan orang tua) ijbar adalah suatu pemaksaan terhadap hak-hak azasi manusia. Oleh karena itu perlu adanya pemahaman baru terhadap konsep ijbar.

Konsep ijbar bukan berarti ayah atau kakek memaksa anak perempuan untuk menikah tanpa seijin anak perempuan namun perlu adanya musyawarah antara orang tua dengan anak untuk meminta persetujuan.

Bukhari, Abi Abdillah ibn Muhammad ibn Isma'il ibn Ibrahim. 1981. Shahih alBukhari. ttp: Dar al-Fikr.

Bursawi, Isma'il Haqqi. tt. Tafsir Ruh al-Bayan. Beirut: Dar al-Fikr.

Bush. Wacana Perempuan di Lingkungan NU, Sebuah Perdebatan Mencari Bentuk. Taswirul Afkar. Edisi No. 51999.

Bruinessen, Martin Van. 1994. NU: Tradisi, Relasi-Relasi Kuasa, Pencarian Wacana Baru. Yogyakarta: LkiS. 
Daruqutni, Ibn Umar. tt. Sunan al-Daruquth$n i$. Beirut: Dar al-Fikr.

Dewantoro, M. Hajar dan Asnawi (ed.). 1996. Rekonstruksi Fiqh Perempuan dalam Peradaban Masyarakat Modern. Yog yakarta: Ababil, 1996.

al-Dimyati, Sayyid al-Bakri ibn al-Arif Billah Muhammad Syatha. tt. I'anah al-Thalibin. Semarang: Toha Putera.

Dimasyqi, Taqiyyuddin. tt. Kifayat al-Akhyar. Beirut: Dar al-Fikr.

Hasyim, Syafiq. 2001. Hal-Hal Yang Tak Terpikirkan Tentang Isu-isu Keperempuanan Dalam Islam, Bandung: Mizan.

Ismail, M. Syuhudi. 1994. Hadis Nabi yang Tekstual dan Kontektual telaah Ma'anil Hadis yang Universal, Temporal dan Lokal. Jakarta: Bulan Bintang.

Iqbal, Muhammad. 1992. The Reconstruction of Religion Though in Islam. New Delhi: Kitab Bhayan.

al-Khatib, Muhammad al-Syarbini. tt. al-Iqna' fi Hall al-Fazi Abi Syuja 'i. Semarang: Toha Putera.

al-Malibari. tt. Fath al-Mu 'in. ttp: Al-Nasyir Syirkah Asia.

Ma'luf, Louis. 1968. Al-Munjid fi al-Lugat wa al-A 'lam. Beirut: Dar al-Masyrik.

Mas'udi, Masdar F. 1998. Islam dan HakHak Reproduksi Perempuan. Dialog Fiqh Pemberdayaan. Bandung: Mizan
Mawardi, Abu Hasan Ali ibn Habib ibn Muhammad. tt. Al-Nuqth wa al-'Uyun Tafsir al-Mawardi. Beirut: Dar alKutub al-'Ilmiyyah.

Muhammad, Husein. 1999. Kontekstualisasi Kitab Kuning: Tradisi Kajian dan Metode Pengajaran. Dalam Pesantren Masa Depan: Wacana Pemberdayaan dan Transformasi Pesantren. Bandung: Pustaka Hidayah. 2002. Fiqh Perempuan Refleksi Kyai Wacana Agama dan Jender. Yogyakarta: LKIS.

Munawir, Ahmad Warson. 1997. Kamus alMunawir. Surabaya: Pustaka Progresif.

Nasution, Khoiruddin. tt. Peran Wali Nikah dan Kebebasan Wanita. Makalah PSW IAIN Sunan Kalijaga, Yogyakarta: PSW IAIN Yogyakarta

Al-Mut'i, Muhammad Najib. tt. Al-Majmu“ 'ala Syarh al-Muhadzdzab. Mesir: alImam.

Al-Syafi'i, Abi Abdillah Muhammad ibn Idris. tt. al-Umm. ttp: tp.

Al-Tirmidzi, Abu Isa Muhammad ibn Musa ibn al-Dahhaq al-Sulami. 1987. Sunan al-Tirmidzi. Beirut: Dar al-Kutub al'Ilmiyah. 